\title{
Hard Cases and the Politics of Righteousness
}

\section{BY CARL E. SCHNEIDER}

And why beholdest thou the mote that is in thy brother's eye, but considerest not the beam that is in thine own eye?. . . Thou hypocrite, first cast out the beam out of thine own eye; and then shalt thou see clearly to cast out the mote out of thy brother's eye.

-MATTHEW 7:3-5

T The law of bioethics has been the law of cases. Interpreting the common law and the Constitution, judges have written the law of informed consent, abortion, and assisted suicide. Reacting to causes célèbres, legislatures have written the law of advance directives and end of life decisions. The long, sad death of Terri Schiavo eclipsed even the long, sad deaths of Karen Ann Quinlan and Nancy Beth Cruzan in the duration and strength of the attention and passions it evoked. What are Schiavo's lessons?

Hard cases, lawyers say, make bad law. Why? First, hard cases are atypical cases. They present abnormal situations that normal rules do not anticipate and cannot handle. Schiavo is egregiously atypical. Persistent vegetative states are unusual. Few families fight so implacably and repellently. Courtsand even less legislatures, governors, and presidents-rarely encounter cases about withdrawing treatments. Decisions usually take days, not decades.

Second, hard cases make bad law because hard cases force tragic choices — choices where walking toward one blessing means walking away from another. The interests of the Schiavos and the Schindlers were irreconcilable. Ms. Schiavo's interests in living and dying clashed.

The menace of hard cases is that they invite response. But no rule can resolve tragic conflicts well. Even could such a rule be imagined, the law that can manage the hard case mishandles ordinary ones. Thus the best response to hard cases is

Carl E. Schneider, "Hard Cases and the Politics of Righteousness," Hastings Center Report 35, no. 3 (2005): 24-27. usually no response. No system of rules ever produces uniformly good results; the goal of legislation is therefore to devise the system that yields the fewest bad results. The course of wisdom is to learn when bad results must be tolerated.

But who thinks Schiavo a hard case? It has primarily provoked righteous vindication: Had you but listened to me, all would be well. The conventional bioethical and medical wisdom is that the internecine strife that ignited Schiavo would have been extinguished had Ms. Schiavo done her duty and prepared an advance directive. This is a triumph of faith over reason: First, as Rebecca Dresser has noted, a court long ago granted Mr. Schiavo the authority to act for his wife. Second, early on a court found "clear and convincing evidence" that Ms. Schiavo would have wanted to forego food and water in her circumstances. Both rulings did what advance directives would presumably have done, but neither ended her travail.

But suppose Ms. Schiavo had — despite her youth—written a living will. Suppose-heroically-that it accurately and lucidly described a careful decision to refuse food and water in a persistent vegetative state. The Schindlers would still have presented medical evidence that Ms. Schiavo was not in that condition. For that matter, bitter and obdurate litigants don't need a good case to protract litigation endlessly.

Indeed, as Ms. Schiavo's guardian ad litem notes in this issue, the Schindlers "stated that even if Theresa had executed a formal, written living will, they would have fought to have it voided because they did not believe it was consistent with their and her beliefs." And they would have had a point. Living wills call for greater powers to predict circumstances and preferences than most of us can muster. Ms. Schiavo would not only have had to imagine the unimaginable about her physical circumstances, she would also have had to anticipate the ways her social circumstances would affect her medical choices. For instance, had Ms. Schiavo anticipated her parents' inconsolable distress at her death, would she have been willing to perdure?

Far from demonstrating the merit of living wills, Schiavo demonstrates their danger. We are insistently admonished that our wishes will be followed if we make living wills. How? Often, just by signing a form from the internet. But many of us cannot actually read those forms. Few of us understand what medical and social decisions they embody. Most of us sign the form as is, without alterations. Evidently one size fits all. Had Ms. Schiavo signed such a document in such a way, what would it be worth? Do life and death turn on such "evidence"?

But the complacent righteousness of the conventional wisdom is as nothing compared with the outraged righteousness of, for want of better terms, the political left and right. The excesses of the harder right have been much remarked and much reviled. And certainly some harder rightists speak with unfortunate carelessness, unattractive confidence, and unwholesome belligerence.

But the righteousness of the right has already been deplored lavishly enough. I want to discuss a less noticed reaction, one that says much about how we make bioethical pol- 


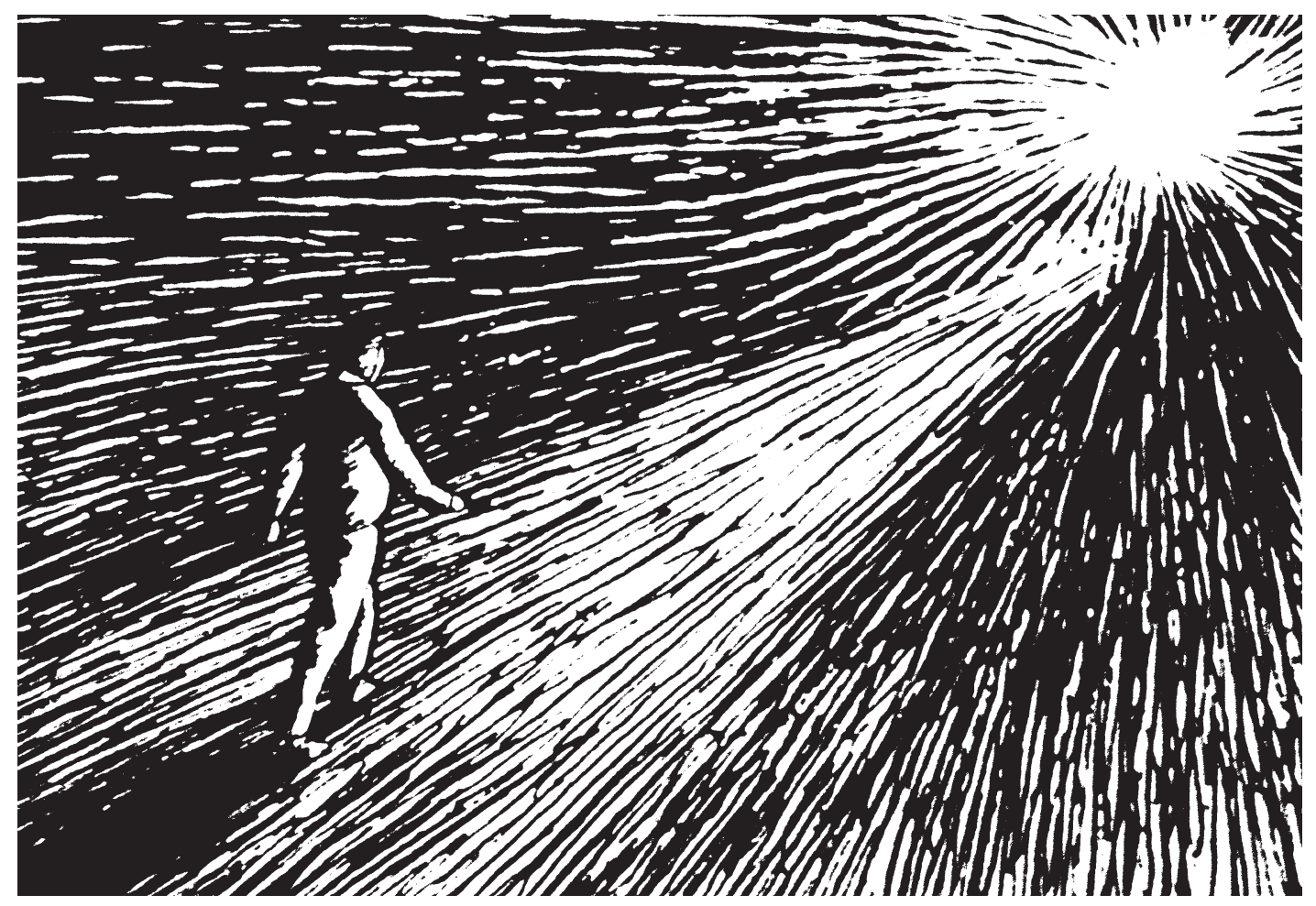

The Light, by Robert Pope.

Used with the permission of the Robert Pope Foundation. icy. The left leapt to dismiss the right as vicious and self-interested: Right-to-life organizations could only be speaking about Ms. Schiavo because they wanted to score points in the abortion debate; Republican politicians could only be voting to win re-election. Quite respectable people deploy quite extravagant terms. The New Republic lamented that "[a]ll the sagacious boundaries were smashed. The machinery of government was twisted to the uses of an ideology and a family." The President "besmirched his oath of office." An op-ed piece in the Los Angeles Times announced that "some social conservatives are happy to see the federal government acquire Stalinist proportions when imposing their morality on the rest of the country."

I got my own taste of this reflexive scorn from one academic I met recently. I mentioned that flu had sentenced me to hours of Schiavo television. Certain I would share his political opinions, my interlocutor made some scoffing remarks about Republicans in Congress. I said he seemed quite contemptuous of his fellow citizens. He seemed startled that I could think of Republicans as fellow citizens: "Sometimes contempt is the only response ...." Republicans were not only self-interested and vicious, they were hypocritical. Their ideas were best explained in sociological, not intellectual, terms. Modernity had passed these poor people by, and their status anxiety led them to cling to laughable religious and social delusions.

I describe this conversation because it exemplifies common attitudes in consequential parts of American society. Consider academia. The range of political views in much of academia — not least in bioethical quarters-is so straitened that it virtually excludes much of ordinary American political opinion. The politics of righteousness has many roots. But one reason so many academics generally and bioethicists particularly embrace it — even relish it —is that they have so few professional opportunities to get to know and understand people who see the world differently from them. Why does diversity find its limits at diversity of opinion?

Left and right meet, then, in the politics of the righteousness. Both preach the gospel of rights. Neither brooks any compromise of the right it favors. Each thinks the other perfidious and two-faced. Neither can imagine learning from the other. And when the politics of righteousness meet a hard case like Schiavo, mutual contumely and improvident policy are the wretched issue.

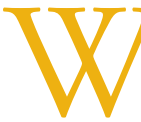

hat would it take to produce wiser policy? Could we treat our fellow citizens as we wish to be treated? First, could we abjure accusations of hypocrisy? Hypocrisy is hard to judge: You cannot fairly determine whether a person's positions contradict his beliefs unless you genuinely understand those beliefs, something the politics of righteousness hardly rewards. And accusations of hypocrisy in politics often mean "you are abandoning your views and agreeing with me." A strange criticism.

Second, might some of our opponents sometimes be right in some things? "I beseech you, in the bowels of Christ, think it possible you may be mistaken." Could we listen to our opponents' most reasonable leaders, look for their most 
thoughtful positions, and enter sympathetically into their minds? Might a decent regard for the people with whom we share a nation and the certainty of our own fallibility lead us to embrace compromise when compromise is possible?

What if we thus approached the Schindlers' sympathizers? I think they are partly reacting to a large but dimly perceived change in legal and social views about when human life is worth protecting. In particular, the law about how we treat life at its two ends has been transformed in the last few decades.

That transformation is most obvious at the beginning of life. Some thirty years ago, abortion was generally illegal. Today, it is a right. Similarly, law at the end of life has shifted quickly and broadly. Fifty years ago, halting medical treatment was suspect. Now treatment is routinely abandoned, the distinction between declining and withdrawing treatment is moribund, nutrition and hydration have become "medical treatments," and assisted suicide has been mooted as a constitutional right, seriously contemplated in several states, and permitted in one. Finally, we recently adopted a new definition of death. Perhaps any new definition of death would be unsettling, but the new definition was introduced for instrumental reasons, including making organ donation easier, which may increase disquiet.

The transformation is not just in practice; it is in the thinking that underlies it. In Cruzan, for example, the Supreme Court came within one vote of holding that incompetent patients have a constitutional right to refuse life-sustaining treatment. Since incompetent people cannot make their own medical decisions, the dissenters were arguing that surrogates have a constitutional right to refuse treatment for patients. The dissenters thought states could not constitutionally require surrogates to meet a "clear and convincing" evidence standard in making such decisions. Since patients' preferences are often undiscoverable, the dissenters were effectively freeing surrogates to decide for themselves whether patients should live. It takes a keen eye to detect the difference between this and involuntary euthanasia, the traditional bottom of the slippery slope.

The dissents in Cruzan hint at another argument that surfaces regularly in discussions of Schiavo - that these decisions should be made by the family, apparently without governmental interference. This view extends the argument frequently made about abortion-that it is a "private decision" in which the state may not "impose" its moral preferences. In the abortion context, that argument assumes that the fetus lacks the moral status of a person "in the whole sense" (as the Court put it in Roe v. Wade). But to suppose that the state has no legitimate interest in supervising decisions to end people's lives is, in our legal tradition, astonishing.

These are large changes in how we regard and cherish human life. They are large changes in when and how life may be protected. The changes may well be desirable. They may also be inevitable. But they are consequential enough that they should be scrupulously evaluated. If only because the changes are so recent-and continuing?- - that evaluation has yet to occur. This may legitimately concern the Schindlers' sympathizers.

\section{transformation has not \\ received satisfactorily broad \\ and probing attention, and \\ that it is reasonable to ask \\ whether the changes have \\ taken us where we truly}

want to go.

\section{T} he way the transformation has been accomplished may exacerbate the anxiety the Schindlers' supporters express. First, some of it occurred outside most people's sight. The revolution in abortion law was certainly hard to miss, but the new definition of death and the new practices at the end of life have been largely managed by experts outside public view. New practices evolved as doctors and patients made decisions and as courts intermittently joined in. Schiavo may have stimulated so much indignation in part because many people had no idea things had gone so far.

Second, the changes have often escaped productive social discussion. It is not enough that people know about large social and legal developments. Such changes should also be the subject of genuine social debate, debate that accommodates the whole range of opinion and that can actually affect law and social practice. Some of the changes I have described, however, have occurred in forums that make such debate im- 
possible. For example, referenda and legislation have been the occasion for fruitful conversation about assisted suicide. But much more change has unfortunately been driven by constitutional litigation.

Two problems with constitutional litigation as the engine of change are relevant to Schiavo. First, constitutional litigation narrows the scope of debate to fit the awkward and artificial categories of due-process analysis. Legal logic supplants moral reasoning. Rules must fit the authority of the court, not the needs of the problem. Second, constitutional litigation is inimical to democratic discourse. It takes issues away from citizens and confides them to judges, lawyers, and a few clients.

Roe $v$. Wade (perhaps the epicenter of the politics of righteousness) illustrates these problems disturbingly well. In the late 1950s, abortion laws began to be re-examined. Between 1967 and 1971, seventeen states amended their abortion laws. California's statute effectively and New York's statute expressly made abortion widely available. But just as the democratic process was working thoughtfully and usefully, the Court decided Roe and arrogated the issue to itself.

As an exercise in moral inquiry or legal analysis, the Court's opinion has few defenders. In it, ipse dixit supplants reasoning: "[W]e do not agree that, by adopting one theory of life, Texas may override the rights of the pregnant woman." Why not? The state has an "important and legitimate interest in potential life," but that interest does not override the mother's rights until the fetus is viable. Why not? "We need not resolve the difficult question of when life begins." Why not? Roe may establish a good system for regulating abortion, but such deficient reasoning about human life should not be its basis.

As an exercise in politics, Roe was ill considered and inept. Political institutions were working toward a compromise on abortion without inciting the political fury that Roe has afflicted us with. That fury, I think, comes partly from the substance of what the Court did, but also from the way it suppressed the processes of democracy. As Judge Calabresi wrote, "The Court, when it said that fetuses are not persons for purposes of due process, said to a large and politically active group: 'Your metaphysics are not part of our Constitution." The Court told them "they could not be true Americans so long as they held to their beliefs. This was catastrophic because it reinforced doubts which the holders of anti-abortion beliefs already had about their full acceptance in American society." All this helps explain some of the attacks on courts that, on my reading of the Schiavo litigation, seem so misplaced.

Happily, the Supreme Court may have learned from its chastening experience with Roe. In Glucksberg v. Washington, the Supreme Court declined to create a constitutional right to the assistance of a physician in committing suicide exactly because Americans were "engaged in an earnest and profound debate about the morality, legality, and practicality of physician-assisted suicide." The Court stayed its hand to "permit this debate to continue, as it should in a democratic society."

$\checkmark$

T have been arguing that if we hear the Schindlers' supporters in the generous spirit I have urged, we perceive that understandings about the ways we value human life have changed rapidly and deeply, that this transformation has not received satisfactorily broad and probing attention, and that it is reasonable to ask whether the changes have taken us where we truly want to go. It is especially reasonable if you share the views about human life that animate many opponents of abortion.

As Rebecca Dresser argues, the failure of the living will and the limits of surrogate judgment now compel us to consider whether we can give useful meaning to a "best interests" test for those incompetent patients for whom no one speaks. Because the law of bioethics is the law of cases, any progress we make is likely to grow out of disputes. In resolving them, as in "nearly all the important transactions of life," wrote James Fitzjames Stephen, "we have to take a leap in the dark. ... . [W] have to act for the best, and in nearly every case to act upon very imperfect evidence." We will accomplish this task best if we renounce the politics of righteousness.

I began by saying that hard cases are misleading. Not least, they distract us from graver but grayer issues. Our health system has many problems more pressing than making decisions for incompetent patients. For example, many more people are tormented by the notorious and scandalous undertreatment of pain in American medicine. In one large study of seriously ill patients, half "complained of pain and one sixth reported extremely severe pain of any frequency or moderately severe pain occurring at least half of the time." The undertreatment of pain afflicts millions and millions more dying patients - and chronically ill patients - than improvident decisions for incompetent patients. Must we await another hard case to address it?

Gaudy hard cases are misleading in another way. One of Schiavo's curses is that it seems to teach us that decisions for incompetent patients are routinely bungled. However, the evidence, while spotty and shallow, suggests that this is false, at least for dying patients. Decisions ordinarily seem to be made as a consensus grows among the physicians and the family that further treatment is bootless. This process is not usually prolonged nor unduly disputatious. We cannot know whether the decisions are "right," but they are normally made the way most patients want- thoughtfully and by people who love them. 